\title{
PEMANFAATAN CITRA LANDSAT 8 UNTUK PENENTUAN KORELASI INDEKS VEGETASI DENGAN KADAR KLOROFIL TANAMAN PADI DI KECAMATAN KOTO TANGAH KOTA PADANG
}

\author{
Hanifa Fitri \\ Jurusan Geografi, Fakultas Ilmu Sosial Universitas Negeri Padang \\ Email: hanifafitri72@gmail.com
}

\begin{abstract}
Abstrak
Klorofil merupakan zat utama pada daun yang berfungsi sebagai alat fotosintesis dan secara tidak langsung akan mempengaruhi hasil produksi padi. Penggunaan Landsat 8 sangat banyak manfaatnya bagi pertanian, diantaranya untuk mengetahui kadar klorofil pada tanaman padi sehingga dapat ditentukan kesehatan tanaman, dan kesehatan tanaman juga bisa ditentukan dari kadar klorofil padi. Penelitian ini dilakukan di Kecamatan Koto Tangah Kota Padang yang bertujuan untuk mengetahui korelasi antara nilai Indeks Vegetasi dengan kadar klorofil pada tanaman padi. Metode yang digunakan dalam penelitian ini yaitu uji labolatorium dengan spektrofotometri dan metode regresi linier sederhana untuk mengetahui korelasi antara kedua variabel. Data yang digunakan dalam penelitian ini yaitu data primer dan data sekunder. Data primer berupa pengambilan sampel daun padi dan koordinat titik sampel, sedangkan data sekundernya adalah citra landsat 8 yang diperoleh dari website USCS. Daun padi yang diambil akan diukur kadar klorofilnya mengunakan metode Wintermans and De Mots denganalat Spektrofotometer. Hasil pengukuran tersebut selanjutnya dikorelasikan dengan indeks vegetasi dari citra satelit menggunakan SPSS. Berdasarkan hasil regresi maka didapatkan korelasi yang paling kuat yaitu $N D G l$ dengan nilai $R^{2}=0.760$ dan persamaan regresi linier $Y=0.007+0.004 x$.
\end{abstract}

Kata kunci : Spektrofotometer, Klorofil, Indeks Vegetasi, Landsat 8.

\begin{abstract}
Chlorophyll is the main substance in the leaves that serves as a means of photosynthesis and will indirectly affect the yield of rice production. The use of Landsat 8 is very useful for agriculture, among others to know the chlorophyll content in rice plants so that can be determined plant health, and plant health can also be determined from rice chlorophyll content. This research was conducted in District Koto Tangah in Padang City which aims to know the correlation between Vegetation Index value with chlorophyll content of rice plants. The method used in this research using laboratory test with spectrophotometry and simple linear regression method to know the correlation between the two variables. The data used in this research are primary data and secondary data. Primary data are sampling of rice leaf and point coordinate, while secondary data is landsat 8 image obtained from USGS website. Rice leaves taken will be measured chlorophyll content using Wintermans and De Mots method with Spectrophotometer. The measurement results correlated with the vegetation index of the satellite image using SPSS. Based on the results of the regression obtained the strongest correlation is NDGl with value $R^{2}=0.760$ and linear regression equation $Y=$ $0.007+0.004 x$
\end{abstract}

Keywords: Spectrophotometer, Chlorophyll, Vegetation Index, Landsat 8.

PENDAHULUAN

Bagi sebagian besar bangsa-bangsa di

Asia, tanaman padi merupakan penghasil pangan pokok yang belum tergantikan. Apalagi bangsa Indonesia yang sebagian besar penduduknya adalah konsumen 
beras.Tidak heran jika sejak awal orde baru, pembangunan ekonomi nasional ditekankan pada bidang pertanian yang berorientasi pada swasembada pangan, khususnya beras. Pada tahun 1984, Indonesia menyatakan diri sebagai negara swasembada beras setelah melalui berbagai program dal3am pembangunan lima tahun (PELITA), baik program ekstensifikasi maupun intensifikasi (Guntoro, 2011:21).

Padi merupakan salah satu tanaman pertanian penting di Indonesia karena beras adalah makanan utama yang dikonsumsi oleh sebagian besar masyarakat Indonesia. Ketahanan pangan telah lama menjadi kebijakan penting di Indonesia. Kebijakan ini umumnya berhubungan dengan swasembada beras. Beras merupakan komoditas unik tidak saja buat Indonesia, tetapi juga buat sebagian besar Negara-negara Asia. Buat Indonesia, beras menjadi komoditas unik tidak saja dilihat dari sisi produsen, konsumen, pemerintah tetapi juga pemanfaatan investasi yang telah dikeluarkan pemerintah serta mulitfungsi sawah itu sendiri(Amang \& M., 1999).

Produksi pertanian di Kota Padang masih di dominasi tanaman padi sawah. Dimana pada tahun 2014 produksi padi sawah di kota Padang mencapai 90.064 ton, namun pada tahun 2015 mengalami penurunan 1,46 persen atau menjadi 88.752 ton (BPS, 2016:204).

Berdasarkan data dari BPS tahun 2014-2015 menunjukan terjadinya penurunan produksi tanaman padi pada Kecamatan Koto Tangah Kota Padang pada tahun 2014 ke tahun 2015. Adapun pada tahun 2014 produksi padi yaitu 18.850 ton sedangkan pada tahun 2015 yaitu 16.632 ton. Berdasarkan data tersebut maka terjadi penurunan produksi padi sebesar 2.218 ton.

Klorofil adalah komponen penting pada tanaman padi untuk aktivitas fotosintesis, yang menghasilkan karbohidrat untuk membentuk jaringan tanaman dan biji padi.Jumlah dan kualitas klorofil tanaman sangat menentukan hasil produksi tanaman padi pada saat panen. Klorofil (dari bahasa Inggris, chlorophyll) atau zat hijau daun (terjemah langsung dari bahasa Belanda, bladgroen) adalah pigmen yang dimiliki oleh berbagai organisme dan menjadi salah satu molekul berperan utama dalam fotosintesis (Wikipedia, Klorofil, 2017).

Penurunan produksi padi di Kecamatan Koto TangahKota Padang menandakan ada permasalahan pada tanaman padi tersebut yang membuat padi kurang produktif dari tahun sebelumnya. Kesehatan dan produktivitas padi dapat dilihat dengan menjadikan daun tanaman padi sebagai indikatornya, karena daun merupakan tempat utama proses fotosintesis (Nuarsa, 2014).

Seperti pada paragraf yang telah penulis uraikan di atas bahwa jumlah dan kualitas klorofil tanaman sangat menentukan hasil tanaman padi saat panen.Penting untuk dilakukan pemantauan pada tamaman padi sebelum panen untuk mengurangi dampak penurunan produksi padi dengan melihat kadar klorofil pada tanaman padi tersebut. Adapun pemantauan yang cepat dan efisien yaitu menggunakan teknologi penginderaan jauh dengan menganalisis indeks vegetasi pada citra penginderaan jauh. Sehubungan dengan hal ini, maka perlu dilakukan penelitian tentang hubungan nilai indeks vegetasi dengan kadar klorofil tanaman padi. Berdasarkan penjelasan di atas maka penelitian ini bertujuan untuk mengetahui hubungan nilai indeks vegetasi dengan kadar klorofil tanaman padi.

\section{METODE PENELITIAN \\ Pengolahan Citra Landsat 8}

Penelitian ini menggunakan citra Landsat 8, menimbang citra yang mudah didapat dan memiliki resolusi spektral dan radiometrik yang lebih baik dibandingkan dengan Lansat 7. Disamping itu citra landsat 8 merekam setiap daerah yang sama dalam 16 hari sekali.

Adapun citra Lansat 8 yang digunakan pada penelitian ini diunduh dari situs USCS (earthexplorer.usgs.gov). Citra landsat 8 yang dipakai yaitu pada tanggal 13 Agustus 2017, dengan 17sampel penelitian.

Analisis citra Landsat 8 menggunakan nilai reflektan TOA planetary. Nilai tersebut merupakan hasil dari konversi nilai DN pada 
citra menggunakan persamaan di bawah ini (USCS,2014).

$\rho \lambda^{\prime}=$ MpQcal $+A p$

dimana:

$\rho \lambda^{\prime}=$ Reflektan TOA planetary, tanpa dikoreksi sudut matahari

$M p=$ Perkalian saluran spesifik dengan faktor recalling dari medata (REFLECTANCE_MULT_BAND_ $x$, $x=$ nomor band)

$A p=$ Penambahan saluran spesifik dengan (REFLECTANCE_ADD_BAND_ $x$, $x=$ nomor band/saluran)

Qcal = Kuantisasi dan kalibrasi produk sandar nilai piksel (DN)

TOA reflectance dengan koreksi sudut matahari adalah:

$\rho \lambda=\rho \lambda / \cos \left(\theta_{\mathrm{sz}}=\rho \lambda / \sin \left(\theta_{\mathrm{SE}}\right)\right.$

dimana:

$\rho \lambda=$ Reflektan TOA planetary

$\theta_{\mathrm{SE}}=$ Sudut elevasi matahari local. Sudut elevasi matahari pada pusat citra dalam derajat, nilai ini terdapat pada medata (SUN_ELEVATION)

$\theta_{s z}=$ Sudut solar zenith local

Indeks vegetasi yang digunakan dalam penelitian ini yaitu Normalized Difference Vegetation Index (NDVI), Renormalized Difference Vegetation Index (RDVI), Normalized Difference Greenless Index (NDGI), Redness Index (RI), Ratio Vegetation Index (RVI), Vegetation Index Number (VIN), Transformed Vegetation Index (TVI), dan Difference Vegetation Index (DVI).Adapun persamaan masing-masing indeks vegetasi di atas yaitu sebagai berikut.

$$
\begin{aligned}
& N D V I=(N I R-R) /(N I R+R) \\
& R D V I=(N I R-R) /(\sqrt{ }(N I R+R)) \\
& N D G I=(G-R) /(G+R)
\end{aligned}
$$

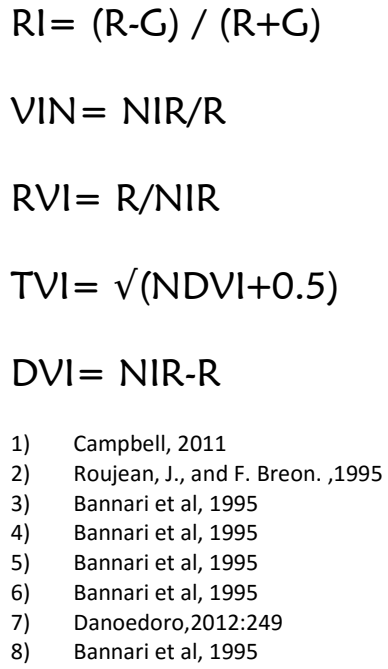

$V I N=N I R / R$

$R V I=R / N I R$

$T V I=\sqrt{ }(N D V I+0.5)$

$D V I=N I R-R$

Dimana NIR, R, dan $\mathrm{G}$ masing-masing adalah saluran inframerah dekat (band 5), saluran merah (band 4) dan saluran hijau (band 3) dari citran Landsat 8. Menentukan hubungan antara indeks vegetasi tersebut dengan kadar klorofil tanaman padi menggunakan regresi linier sederhana dengan persamaan.

$\mathrm{Y}=\mathrm{a}+\mathrm{bx}$

Dimana $Y$ merupakan faktor terikat (klorofil), $x$ merupakan faktor tidak terikat (indeks vegetasi), a merupakan konstanta, dan b merupakan koefisien.

\section{Daerah Penelitian}

Lokasi penelitian dilakukan pada penggunaan lahan sawah di Kecamatan Koto Tangah Kota Padang, Provinsi Sumatera Barat. Adapun untuk luas lahan sawah di Kecamatan Koto Tangah adalah 1794 Ha.Lahan sawah di Kecamatan Koto Tangah merupakan sawah dengan luas terbesar di Kota Padang.

Penelitian ini merupakan kontribusi bidang kajian geografi pada penginderaan jauh, SIC, dan pertanian. Adapun alat dan bahan yang perlu digunakan dalam penelitian ini yaitu GlobalPositional System (GPS), Alat tulis, perangkat komputer, Aplikasi ArcGIS, Aplikasi ENVI 3.8, Aplikasi SPSS, dan kamera sebagai dokumentasi. 


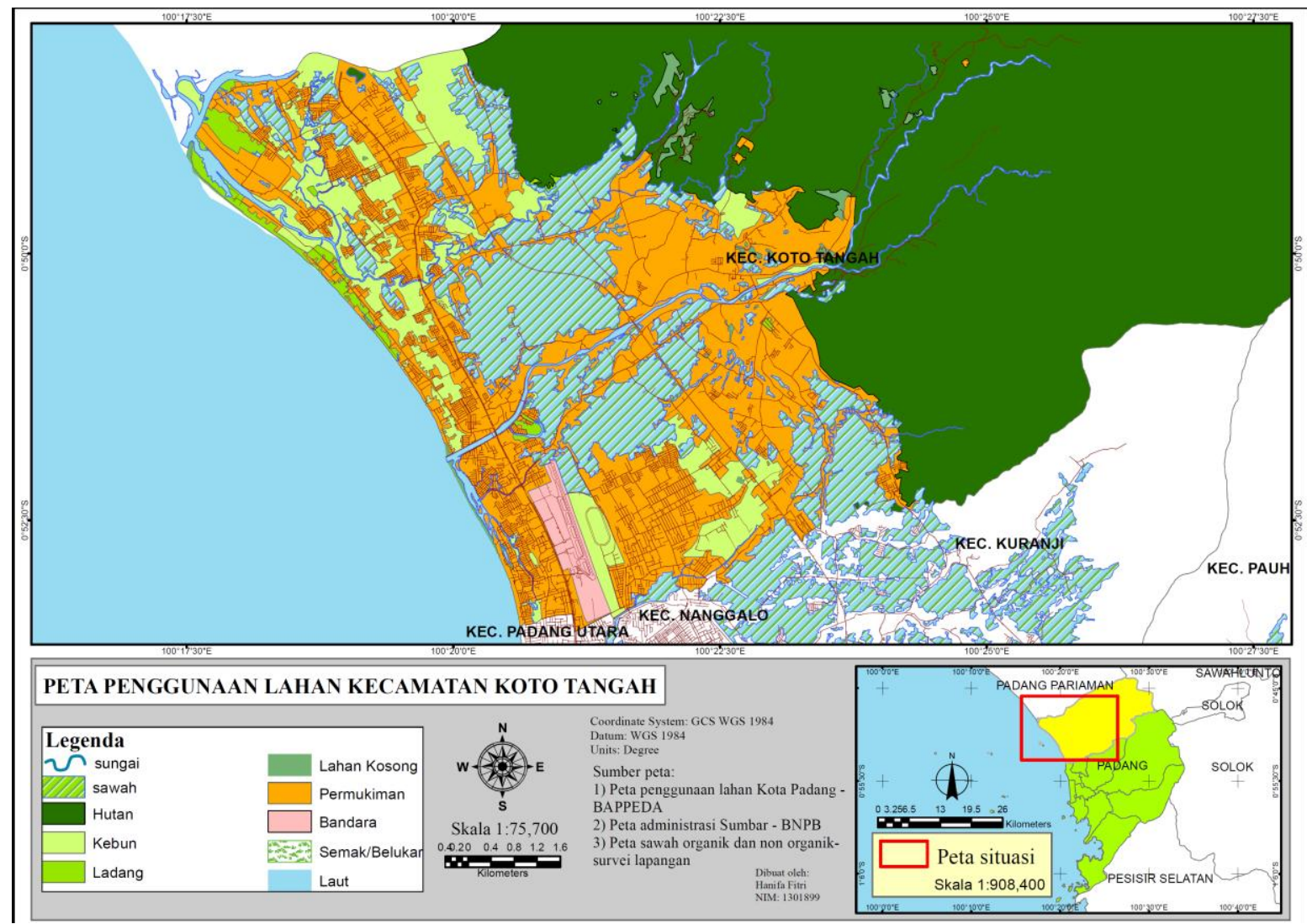

Gambar 1. Peta daerah penelitian, Kecamatan Koto Tangah Kota Padang

\section{HASILDAN PEMBAHASAN \\ Kandungan Klorofil}

Padi merupakan vegetasi yang homogen sehingga termasuk pada penggunaan lahan yang mudah diinterpretasikan pada citra satelit.Peneliti mengambil sampel sebanyak 17 sampel. Daun padi akan dilakukan uji laboratorium di labor Kopertis wilayah X Sumatera Barat untuk mengetahui kadar klorofil daun dalam $\mathrm{mg} / \mathrm{l}$. Metode yang digunakan adalah metode Wintermans and De Mots dengan menggunakan pelarut Ethanol $96 \%$ dan mengukur Absorbansi larutan klorofil pada panjang gelombang 649 dan $665 \mathrm{~nm}$ menggunakan alat Spektrofotometer. Hasil spektrofotometri dari panjang gelombang tersebut akan didapatkan kadar klorofil dengan satuan $\mathrm{mg} / \mathrm{l}$ menggunakan persamaan berikut.

Klorofil $\mathrm{a}=13.7 \mathrm{D} 655-5.67 \mathrm{D} 649(\mathrm{mg} / \mathrm{l})$

Klorofil $b=25.8$ D649 - 7.6 D665 (mg/l)

Klorofil total $=20.0$ D649 -6.10 D665 $(\mathrm{mg} / \mathrm{l})$

Dimana D655 merupakan hasil pengukuran spektrofotometer dengan panjang gelombang $655 \mathrm{~nm}$, D649 merupakan hasil pengukuran spektrofotometer dengan panjang gelombang $649 \mathrm{~nm}$.

Sampel tersebut terdiri dari beberapa fase pertumbuhan padi, diantaranya fase vegetative, fase reproduktif dan fase ripening. 
Tabel 1. Hasil uji laboratorium dan total klorofil

\begin{tabular}{|r|r|r|r|r|r|}
\hline NO & D $649 \mathrm{~nm}$ & D $665 \mathrm{~nm}$ & $\begin{array}{c}\text { Klo a } \\
(\mathrm{mg} / \mathrm{l})\end{array}$ & $\begin{array}{c}\text { Klo b } \\
(\mathrm{mg} / \mathrm{l})\end{array}$ & $\begin{array}{c}\text { Klo total } \\
(\mathrm{mg} / \mathrm{l})\end{array}$ \\
\hline 1 & 0.527 & 1.079 & 11.7468 & 5.3962 & 17.1219 \\
\hline 2 & 0.146 & 0.294 & 3.1868 & 1.5324 & 4.7134 \\
\hline 3 & 0.172 & 0.346 & 3.7495 & 1.8080 & 5.5506 \\
\hline 4 & 1.21 & 2.28 & 24.2664 & 13.8900 & 38.1080 \\
\hline 5 & 0.91 & 1.869 & 20.3637 & 9.2736 & 29.6009 \\
\hline 6 & 0.509 & 1.114 & 12.3300 & 4.6658 & 16.9754 \\
\hline 7 & 0.54 & 1.15 & 12.6446 & 5.1920 & 17.8150 \\
\hline 8 & 0.644 & 1.312 & 14.2650 & 6.6440 & 20.8832 \\
\hline 9 & 0.654 & 1.38 & 15.1390 & 6.3852 & 21.4980 \\
\hline 10 & 1.071 & 2.111 & 22.7517 & 11.5882 & 34.2971 \\
\hline 11 & 0.691 & 1.471 & 16.1725 & 6.6482 & 22.7931 \\
\hline 12 & 1.133 & 2.207 & 23.7098 & 12.4582 & 36.1227 \\
\hline 13 & 0.877 & 1.791 & 19.4852 & 9.0150 & 28.4651 \\
\hline 14 & 0.853 & 1.751 & 19.0754 & 8.6998 & 27.7411 \\
\hline 15 & 0.975 & 0 & -5.6160 & 25.1550 & 19.5000 \\
\hline 16 & 0.603 & 1.224 & 13.2955 & 6.2550 & 19.5264 \\
\hline 17 & 0.613 & 1.196 & 12.8543 & 6.7258 & 19.5556 \\
\hline
\end{tabular}

Sumber: Hasil Penelitian, 2017

\section{Korelasi Indeks Vegetasi dengan Kadar} Klorofil Tanaman Padi

Klorofil sangat penting pada tanaman karena merupakan tempat utama fotosintesis, jika proses fotosintesis terganggu maka makanan bagi tanaman juga akan terganggu, akibatnya kesehatan dan produktifitas tanaman menjadi kurang baik. Maka secara tidak langsung klorofil mempengaruhi hasil produksi pada tanaman. Berdasarkan penjelasan ini maka perlu dilakukan pemantauan pada tanaman padi sebelum panen. Pemantauan yang paling mudah dan cepat yaitu menggunakan citra Landsat .

Tabel 2. Nilai indeks vegetasi dan kandungan kadar klorofil tanaman padi

\begin{tabular}{|r|c|c|c|c|r|c|c|r|r|}
\hline $\begin{array}{r}\text { No } \\
\text { sampel }\end{array}$ & NDVI & NDGI & RI & RVI & VIN & TVI & RDVI & DVI & Klorofil \\
\hline 1 & 0.313409 & 0.060886 & -0.06089 & 0.322921 & 3.096732 & 0.395859 & 0.314088 & -0.19275 & 17.1219 \\
\hline 2 & 0.248846 & 0.009269 & -0.00927 & 0.415045 & 2.409378 & 0.352736 & 0.248224 & -0.14905 & 4.7134 \\
\hline 3 & 0.270574 & 0.047165 & -0.04717 & 0.371298 & 2.693255 & 0.367814 & 0.268629 & -0.1574 & 5.5506 \\
\hline 4 & 0.394533 & 0.154059 & -0.15406 & 0.229147 & 4.36401 & 0.444147 & 0.398797 & -0.25359 & 38.108 \\
\hline 5 & 0.373449 & 0.14576 & -0.14576 & 0.24495 & 4.082462 & 0.432116 & 0.37487 & -0.23171 & 29.6009 \\
\hline 6 & 0.236435 & 0.068733 & -0.06873 & 0.415623 & 2.405996 & 0.343828 & 0.233372 & -0.13193 & 16.9754 \\
\hline 7 & 0.233424 & 0.071734 & -0.07173 & 0.422503 & 2.36685 & 0.341631 & 0.230554 & -0.13093 & 17.815 \\
\hline 8 & 0.326553 & 0.115999 & -0.116 & 0.293591 & 3.406102 & 0.404075 & 0.325197 & -0.19366 & 20.8832 \\
\hline 9 & 0.268735 & 0.066292 & -0.06629 & 0.386866 & 2.584875 & 0.366561 & 0.268757 & -0.16338 & 21.498 \\
\hline 10 & 0.370374 & 0.112348 & -0.11235 & 0.271583 & 3.682109 & 0.430334 & 0.378299 & -0.24983 & 34.2971 \\
\hline 11 & 0.296191 & 0.084346 & -0.08435 & 0.337969 & 2.958853 & 0.384832 & 0.295035 & -0.17592 & 22.7931 \\
\hline 12 & 0.423534 & 0.165665 & -0.16567 & 0.207448 & 4.820481 & 0.460181 & 0.432237 & -0.28463 & 36.1227 \\
\hline 13 & 0.369763 & 0.143842 & -0.14384 & 0.250601 & 3.990399 & 0.429979 & 0.37141 & -0.23021 & 28.4651 \\
\hline 14 & 0.262404 & 0.102063 & -0.10206 & 0.388129 & 2.576465 & 0.362218 & 0.261033 & -0.15458 & 27.7411 \\
\hline 15 & 0.351842 & 0.124621 & -0.12462 & 0.257957 & 3.876609 & 0.419429 & 0.350165 & -0.20787 & 19.5 \\
\hline 16 & 0.328846 & 0.092368 & -0.09237 & 0.314178 & 3.182912 & 0.405491 & 0.332592 & -0.21197 & 19.5264 \\
\hline 17 & 0.315025 & 0.063087 & -0.06309 & 0.345325 & 2.895825 & 0.399393 & 0.327819 & -0.22084 & 19.5556 \\
\hline
\end{tabular}

Sumber: Hasil Penelitian, 2017 


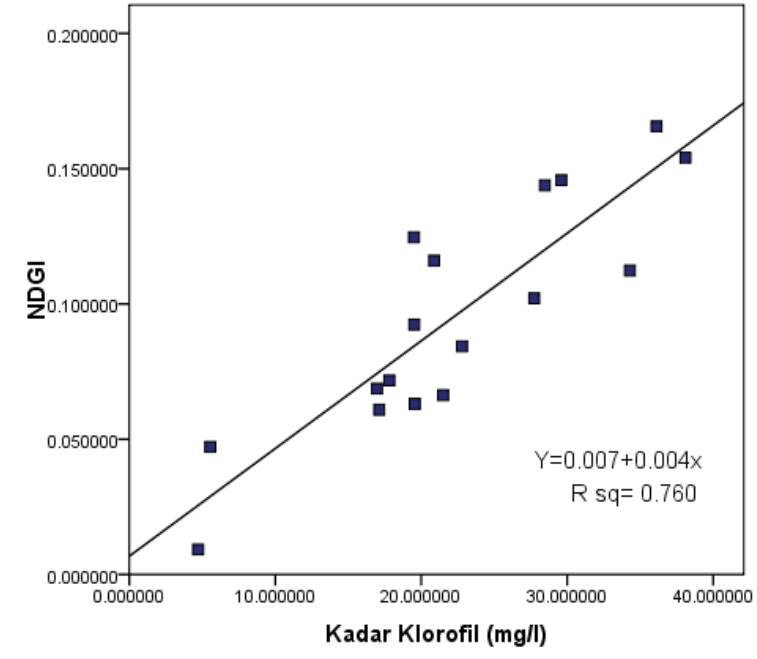

Gambar 2. Hubungan nilai NDGI dengan kadar klorofil tanaman padi

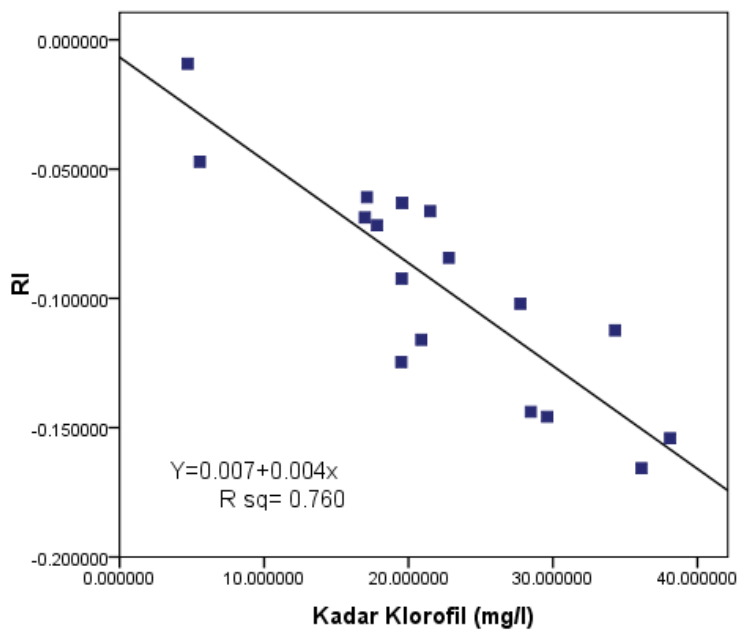

Gambar 3. Hubungan nilai RI dengan kadar klorofil tanaman padi

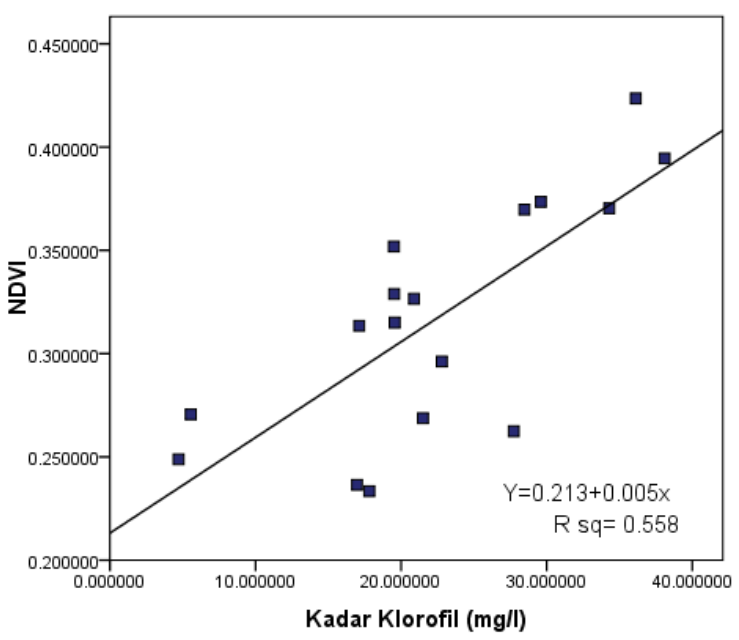

Gambar 4. Hubungan nilai NDVI dengan kadar klorofil tanaman padi

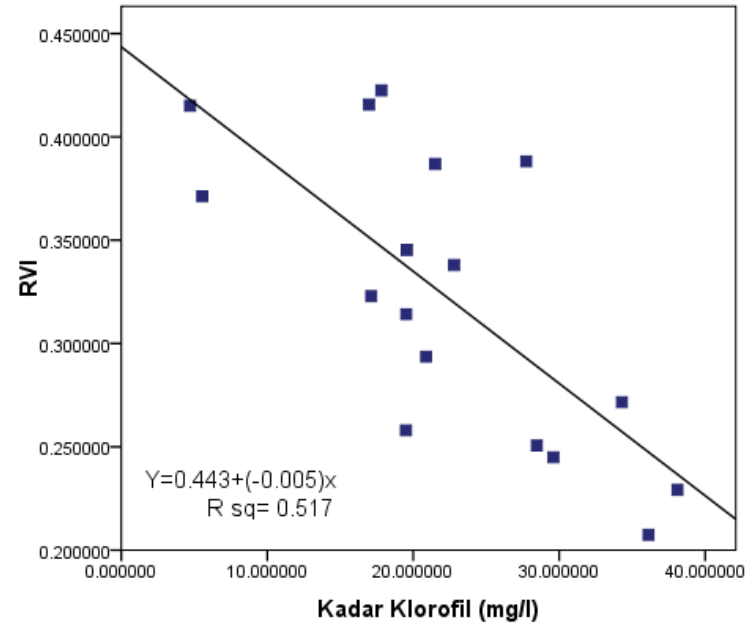

Gambar 5. Hubungan nilai RVI dengan kadar klorofil tanaman padi

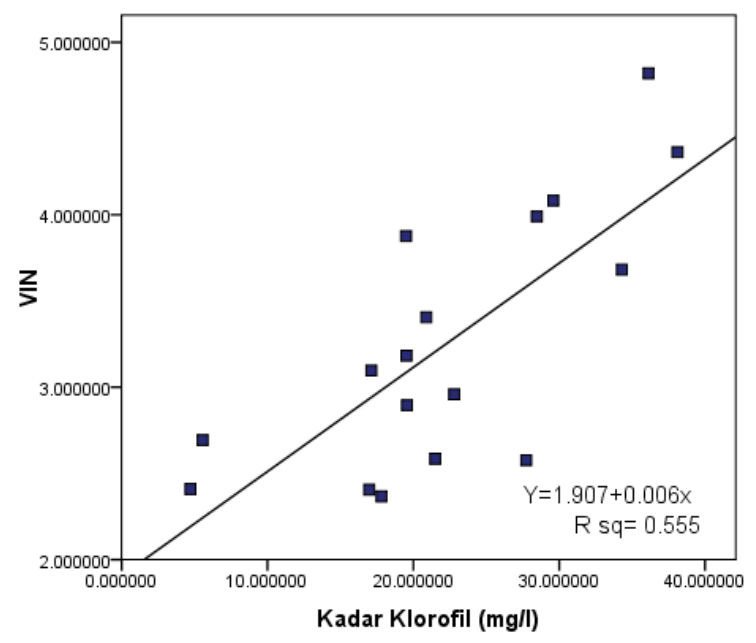

Gambar 6. Hubungan nilai VIN dengan kadar klorofil tanaman padi

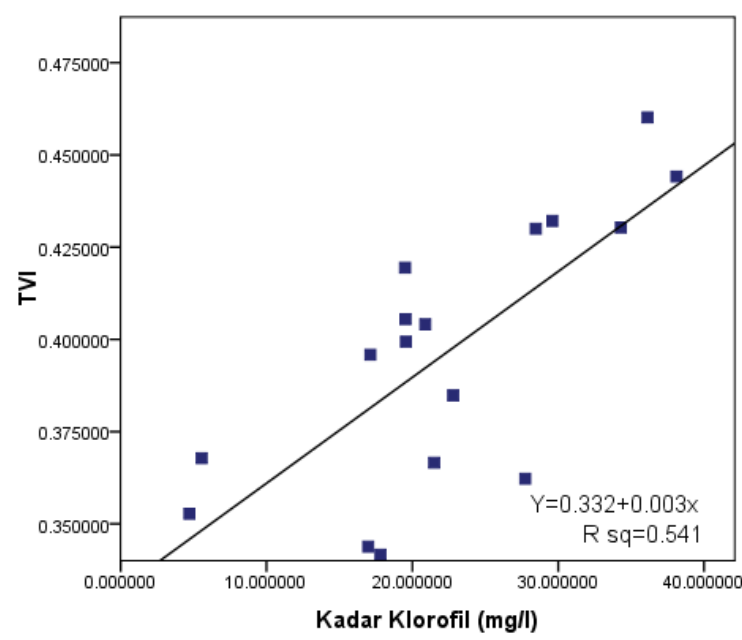

Gambar 7. Hubungan nilai TVI dengan kadar klorofil tanaman padi 


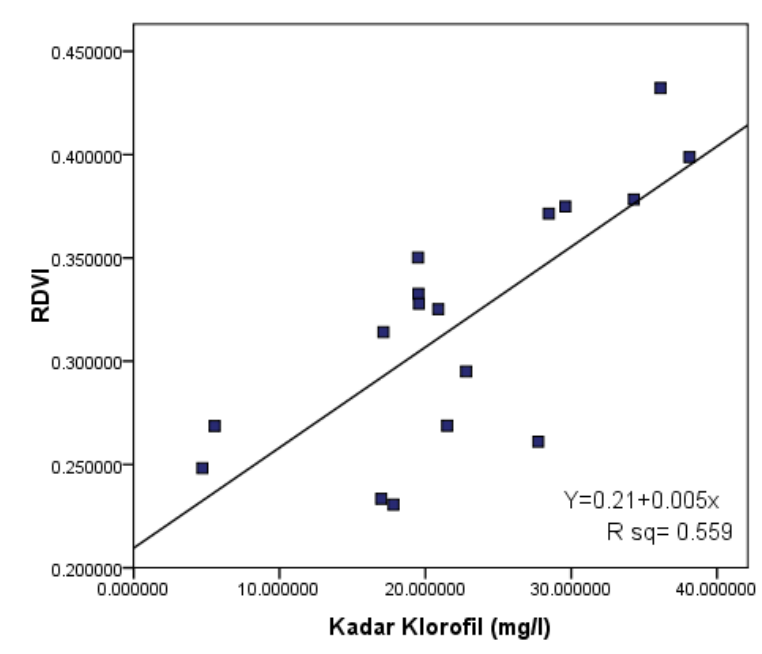

Gambar 8. Hubungan nilai RDVI dengan kadar klorofil tanaman padi

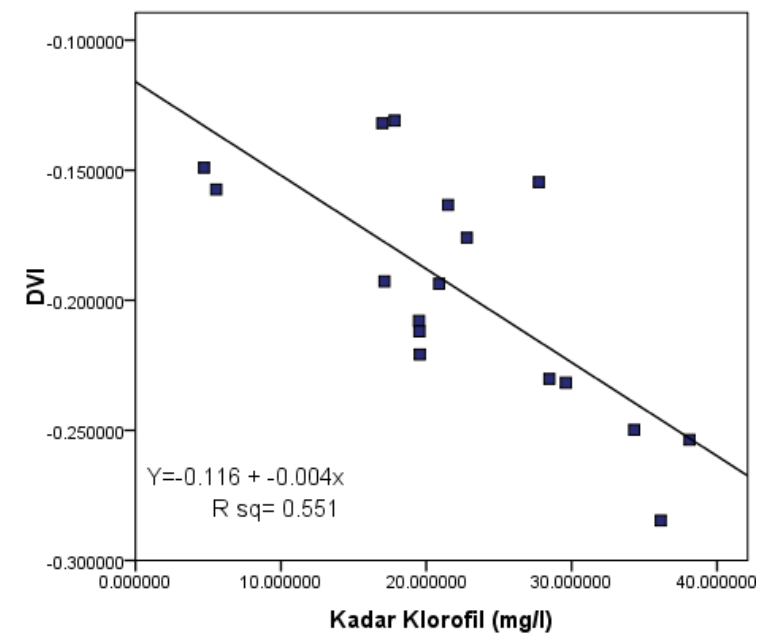

Gambar 9. Hubungan nilai DVI dengan kadar klorofil tanaman padi

Dari kedelapan Indeks Vegetasi yang dievaluasi dalam penelitian ini menyatakan bahwa NDGI menunjukkan hubungan yang paling kuat dengan kandungan kadar klorofil tanaman padi dengan nilai $\mathrm{R}^{2}=0.760$, diikuti oleh $\mathrm{RI}$ dengan nilai $\mathrm{R}^{2}$ yang sama, RDVI dengan nilai $R^{2}=0.559$, NDVI dengan nilai $\mathrm{R}^{2}=0.558$, $\mathrm{VIN}$ dengan $\mathrm{R}^{2}=0.555$, $\mathrm{DVI}$ dengan $\mathrm{R}^{2}=0.551$, TVI dengan $\mathrm{R}^{2}=0.541$, dan $\mathrm{RVI}$ dengan $\mathrm{R}^{2}=0.517$.

\section{KESIMPULAN}

Berdasarkan hasil survey lapang dan analisis citra Landsat 8 , beberapa kesimpulan yang dapat diambil pada penelitian ini yaitu bahwa indeks vegtasi NDGI mempunyai hubungan yang paling erat dengan klorofil dibanding Indeks Vegetasi lain dengan nilai $\mathrm{R}^{2}=0.760$. Bentuk persamaan hubungan tersebut yaitu $Y=0.007+0.004 x$, dimana $y$ merupakan kandungan klorofil dan $x$ merupakan NDGI.

\section{DAFTAR PUSTAKA}

Amang, B., \& M., H. S. (1999). Kebiajakan Beras dan Pangan Nasional. Jakarta: IPB Press.

Badan Pusat Statistik. (2015). Kota Padang Dalam Angka 2015. Padang: BPS.

Badan Pusat Statistik. (2016). Kota Padang Dalam Angka 2016. Padang: BPS.

Bannari, A., Asalhi, H., \& Teillet, P. M. (2002). Transformed difference vegetation index (TDVI) for vegetation cover mapping.

Banowati, E., \& Sriyatno. (2013). Geografi Pertanian. Yogyakarta: Ombak.

Campbell, J. B., \& Wynne, R. H. (2011). Introduction to Remote Sensing Fifth Edition. New York: Guildford Press.

Danoedoro, P. (2012). Pengantar Penginderaan Jauh Digital. Yogyakarta: ANDI.

Guntoro, S. (2011). Saatnya Menerapkan Pertanian Tekno-Ekologis. Jakarta: Agromedia Pustaka.

Nuarsa, I. W. (2014). Penggunaan Citra Landsat 8 untuk Estimasi Kadar Khlorofil dan Hasil Tanaman Padi. Jurusan Agroekoteknologi, VOL. 4, NO. 1 (2014).

Roujea, J.-L., \& Breon, F. M. (1995). Estimating PAR Absorbed by Vegetation from Bidirectional Reflectance Measurements. 51:375-384 (1995).

USCS. (2014). Using the USCS Landsat 8 Product. U.S. Geological Survey. 
http://landsat.usgs.gov/Landsat8_Using_ Product.php.

Wikipedia. (2017, Januari 26). Klorofil.

Dipetik Maret 15, 2017, dari Wikipedia:

https://id.wikipedia.org/w/index.php?titl

$\mathrm{e}=$ Klorofil\&oldid $=12213718$ 